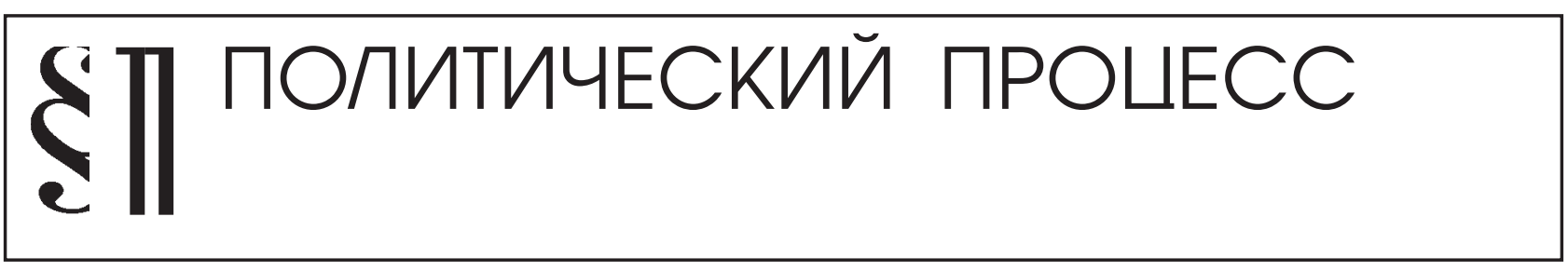

Беляев А.Ю.

\title{
ЗАКОНОМЕРНОСТИ ИЗБИРАТЕЛЬНОГО ПРОЦЕССА, ИХ ИСПОЛЬЗОВАНИЕ В ИССЛЕДОВАТЕЛЬСКОЙ ПРАКТИКЕ
}

Аннотация: В статье раскрываются основные закономерности избирательного процесса, характерные для отечественной и зарубежной избирательной практики. Анализируются и конкретизируются содержание отдельных из них. Раскрывается сущность таких явлений как абсентеизм, плюрализм, политический рынок, джерримандеринг и др. в преломлении к избирательной практике. Дается оценка гносеологической значимости обозначенных закономерностей, сделана попытка их систематизации.

Ключевые слова: Политология, избирательный прочесс, избирательные кампании, выборы, партии, политический рынок, джерримандеринг, политическая конкурениия, плюрализм, абсентеизм

И збирательный процесс не стихиен по своей природе и механизму осуществления. В нем просматриваются закономерности, сущностные элементы, целеполагание. Под закономерностями избирательного процесса следует понимать необходимые, относительно устойчивые и постоянно воспроизводимые отношения между избирателями и политическими акторами по поводу образования и функционирования власти ${ }^{1}$.

В теоретическом аспекте возможно вычленение общих, присущих любой избирательной системе, и закономерностей, характерных для российской избирательной практики. К первым можно отнести следующие:

1. Многофакторность природы и содержания избирательного процесса.

В первую очередь, состояние политической системы является одним из факторов, определяющих направленность избирательного процесса. Наличие обратной связи между властью и обществом, четкое соблюдение правовых норм, регулирующих политическую сферу, а также состояние других компонентов политической системы и, кроме того, уровень откры-

${ }^{1}$ Анцииферова И. В. Избирательный процесс: социологический анализ. М. - 2009 тости и демократичности влияет на развитие политического процесса.

Также одним из важных факторов избирательного процесса является уровень политического развития основных акторов и уровень их политической ответственности. Так, например, уже второе десятилетие КПРФ и ее лидер Г. Зюганов объединяют вокруг себя лиц коммунистической принадлежности.. Партия стабильно от выборов к выборам проходит в Государственную Думу и демонстрирует высокий процент поддержки избирателей. Сохраняя свое лицо (и сформированный имидж), чувствуя свою ответственность перед избирателями, КПРФ не использует в своей агитационной работе негативные разобщающие темы, например, национальный вопрос и др.

Тогда как партия ЛДПР, к примеру, пошла на декабрьские выборы в Госдуму под лозунгом защиты интересов русских, причем под словом «русские» подразумеваются те, «кто говорит на русском языке», заявил лидер партии В. Жириновский.

Уровень социально-экономического состояния общества также является существенным фактором, характеризующим природу избирательного процесса.

Таким образом, данная закономерность позволяет говорить об ИП как сложной системе, подверженной активному влиянию внешних факторов, таких как: состояние политической системы, эффективность 


\section{Политика и общество 6 (102) • 2013}

государственного управления, уровень развития основных политических акторов, их политической ответственности, расстановка политических сил, социально-экономическое состояния общества и др.

Анализ совокупности этих факторов и позволяет выявить многомерность избирательного процесса.

2. Устойчивое сближение идеологических позиций в избирательном процессе при двухпартийной системе.

При наличии в избирательном пространстве двух крупных партий-«фаворитов», каждая из них для победы должна заручится поддержкой более половины голосов избирателей. Поэтому их программы составлены с учетом интересов различных электоральных групп и лишены радикализма. Зачастую идеологические позиции политических акторов в двухпартийной системе разняться крайне незначительно.

Данная закономерность может быть проиллюстрирована на примере партийной системы в США. Современная двухпартийная система США сложилась к середине 19 в. и состоит из двух основных конкурирующих партий - Республиканской и Демократической. Одной из особенностей данной системы является то, что ни одна из партий не может опираться лишь на одну электоральную группу. Для победы на выборах им необходимо набрать голоса более половины избирателей, и поэтому обе партии в своих программах стараются избегать идеологических крайностей.

3. Прямая зависимость объема партийных ресурсов от характера и уровня избирательной кампании.

В зависимости от уровня избирательной кампании - национальной, региональной, муниципальной - кандидаты и партии выбирают оптимальный бюджет, то есть тот объем финансовых средств, который будет затрачен на проведение данной кампании. Объем выделенных на избирательную кампанию средств определяет количество информации, объем агитации и рекламы, которая дойдет до избирателя.

Финансовые возможности дают возможность политическим конкурентам влиять на объем информации, на степень своего рекламирования, на основе чего избирателями принимаются решения. Таким образом, бюджеты кандидатов в президенты и в муниципальные образования невозможно сопоставить. Этот факт дает понимание того, почему объем наглядной агитации муниципальных выборов, а также агитации в СМИ, например, ничтожно мал по сравнению с выборами в Государственную Думу.
4. Усиление значимости социального фактора в избирательном процессе

Склонность к восприятию популистских идей объясняется в значительной степени неразвитостью политической культуры общества.

Существующая в России социально-культурная дифференциация является одной из главных причин распространенности популизма в законодательной и исполнительной власти. Одним из самых распространенных примеров популизма является принятие законодательными органами власти социальных или экономических законопроектов реально не подкрепленных бюджетом, или же в случае с оппозицией предложение подобных законопроектов.

В условиях демократического общества и при наличии политической конкуренции завоевание электоральной поддержки является одним из главных факторов победы на выборах. Этим и объясняется, что зачастую политические акторы прибегают к использованию популистских обещаний в своих предвыборных программах.

5. Выборы как политический рынок.

Выборы являются таким социально-политическим процессом, который позволяет различным электоральным группам формулировать свои позиции, отвечающие их интересам, и в ходе выборной гонки выступать в поддержку тех политических акторов, которые максимально соответствуют их взглядам и требованиям. Поэтому в демократическом обществе выборы становятся своеобразным политическим рынком, где партии и кандидаты предлагают политические лозунги, программы и обещания в обмен на голоса избирателей.

Таким образом, в политическом пространстве происходит конкурентная борьба юридически равных политических акторов, которые стремятся прийти к власти, предлагая взамен электорату достойных доверия кандидатов, лозунги, идеи, программы и проч.

6. Манипулирование с определением границ избирательных округов («Джерримандеринг»).

Если достаточно хорошо знать конкретное размещение различных социальных групп, т.е. политическую географию общества, то не составит особого труда нарезать сетку округов таким образом, чтобы кардинально сократить политическое влияние одних групп на результаты выборов в угоду другим группам. «Джерримандеринг» - манипуляция границами избирательных округов при их нарезке в интересах определенной группы. 
С проблемой «джерримандеринга» в первую очередь сталкиваются страны, где существует мажоритарная избирательная система, и проводятся выборы в представительный орган власти по одномандатным округам.

Не секрет, что использование методики «джеримандеринга» ущемляет избирательные права граждан. Поэтому необходимо создать такой алгоритм, при котором было бы невозможно использование в избирательном процессе технологий, подобной данной.

Можно выделить вторую группу закономерностей, тех, что присущи российскому избирательному процессу. К ним стоит отнести:

1. Расширение политического пространства в России вследствие увеличения количества политических игроков.

Многопартийность в России претерпевает количественные и качественные изменения. 4 апреля 2012 года Дмитрий Медведев подписал новый закон о партия $\mathrm{x}^{2}$. Этот шаг стал одним из ответов власти на возникшее электоральное недовольство результатами думских выборов, вылившееся в многочисленные митинги оппозиции.

Новый закон предусматривает собой снижение минимальной численности членов партий с 40 тысяч до 500 человек. Кроме того, расширяются возможности партий по подаче регистрационных документов, и упрощается система сдачи отчета - теперь партиям достаточно раз в три года отправлять его в Центризбирком. Данные послабления, по замыслу авторов, должны стимулировать появление на политической арене новых партий. И, действительно, по данным Министерства юстиции РФ количество оргкомитетов по созданию новых партий к 10 апреля (через неделю после вступления в силу закона) составило уже 128 , а в июле официально зарегистрированных партий стало уже $25^{3}$.

Знание данной закономерности позволяет указать на тенденцию дальнейшего расширения политического пространства в избирательном процессе и появления на нем новых политических акторов. Кроме того, интересно проследить какую роль будут играть

2 «Российская газета» - Федеральный выпуск №5746 (73) от 04.04.2012 г.

${ }^{3}$ Список политических партий, зарегистрированных Министерством юстиции Российской Федерации 16.07.2012 (http://www.minjust.ru/node/2285?theme=minjust) вновь зарегистрированные политические партии смогут ли он на равных бороться за власть с уже существующими.

2. Обострение политической конкуренции в процессе выборов вследствие развития многопартийности.

В истории современной России уже был период, когда на политической сцене были представлены не один десяток партий. В 90-е годы после либерализации политического пространства произошел всплеск появления новых партий. Так, например, на выборах в Государственную думу в 1995 году приняли участие 43 партии и объединения ${ }^{4}$. Кроме того, в думах первых созывов партия власти «Наш дом - Россия» не имела парламентского большинства, что позволяло оппозиции блокировать законопроекты, предлагаемые правительством.

Надо отметить, что на 2011 год была достигнута определенная устойчивость партийной системы. На политической арене существовали 7 партий (принимавшие участие в последних выборах), из которых 4 представлены в нижней палате парламента. Кроме того, уже несколько созывов большинство в Государственной Думе принадлежит партии власти. Любые законодательные инициативы, исходящие из правительства беспрекословно принимаются. Интересно, что по данным социологических опросов, население в целом одобряет данную систему и не желает появления новых политических партий ${ }^{5}$.

Однако, при дальнейшей либерализации политического законодательства, еще большем снижении проходного барьера в Думу, появлении возможности формировать блоки, активизацией электоральной активности - вполне возможно появление новых сильных партий и движений. И здесь уже будет зависеть от власти, сможет ли она без ущерба для себя вписаться в новую партийную систему.

Выборы в местные законодательные органы власти демонстрируют, что партийная конкуренция возросла пока только в количественном показателе, но не в качественном. Так, например, на выборах депутатов Саратовской областной Думы пятого созыва приняло

${ }^{4}$ Сводная таблица Центральной избирательной комиссии Российской Федерации о результатах выборов депутатов Государственной Думы Федерального Собрания Российской Федерации второго созыва

${ }_{5}^{5}$ Исследование ФОМ(Фонд Общественное Мнение) Нужны ли новые партии? (http://fom.ru/partii/10296) 


\section{Политика и общество 6 (102) • 2013}

участие 13 партий. Однако набрать хотя бы более $1 \%$ голосов удалось лишь 5 партиям, а преодолеть рубеж в 5\% - лишь трем. Кроме того, партия «Единая Россия» победила с подавляющим преимуществом, показав результат $77,92 \%{ }^{6}$.

3. Партийно-идеологическая диверсификация в плюралистическом обществе.

Электоральные предпочтения в российском обществе крайне неоднородны, а потому в современном политическом пространстве существует множество партий и объединений различной идейно-идеологической направленности.

Левые популисты придерживаются уравнительных настроений. Тогда как более радикально настроенная их часть выступает за реставрацию советского прошлого, возврат к плановой экономике и проч.

Кроме того, в российском политическом пространстве распространен популизм патриотической направленности. К нему апеллируют как представители левого, так и правого толка.

Популизм правой направленности присущ российским радикальным силам - националистам и фашистам. Основными задачами они видят изгнание из своих субъектов людей некоторых национальностей, формирование властных органов по национальным признакам и проч.

Решение социально-экономических проблем представители умеренных правых взглядов видят в приведении основных стандартов к общемировым, не беря в расчет российскую специфику.

Потребность консервативной части электората, которая выступает за экономическую стабильность, политическую преемственность и пр., призвана удовлетворить партия Единая Россия.

4. Неразвитость политической культуры избирателей в России как основная причина абсентеизма.

Одной из главных особенностей современной российской политической культуры является низкий уровень доверия к власти. Это объясняется многими историческими предпосылками: долгой невозможностью населения реально влиять на развитие политического процесса, длительным отчуждением простых граждан от властных структур, фактическим отсутствием политических свобод, неразвитостью институтов гражданского общества и др. ${ }^{6}$ Постановление № 26/1-5 от 16 октября 2012 года ЦИК Рос-
сии в Саратовской области
Помимо этого в России отсутствуют общепринятые политические ценности и, как следствие этого, неразвит процесс политическая социализации, которая формирует у граждан основные политические ориентиры.

Неразвитость политической культуры выступает одной из главных причин развития абсентеизма, то есть игнорирование гражданами своих избирательных прав, неучастие в голосовании. Данное явление является отражением протестных настроений, неверия власти, чувства непредсказуемости и неверия политике, утраты интереса к политической деятельности и проч.

Одним из последних примеров политического абсентеизма в России могут служить губернаторские выборы 14 октября 2012 года в Амурской области, явка на которых составила $32.98 \%$.

Тенденция абсентеизма негативно сказывается на развитии избирательного процесса, кроме того она демонстрирует неудовлетворенность населения возможностями политического выбора.

Таким образом, для избирательного процесса характерен целый ряд закономерностей. В теоретико-методологическом аспекте важно выявление их инструментальной роли и значимости. Анализ, детальное изучение закономерностей позволяет раскрыть природу, сущность, механизмы избирательного процесса в целом, определить векторы его эффективного развития, повысить точность политического прогнозирования.

\section{Библиография:}

1. Анциферова И. В. Избирательный процесс: социологический анализ. М. - 2009

2. «Российская газета» - Федеральный выпуск №5746 (73) от 04.04.2012 г.

3. Список политических партий, зарегистрированных Министерством юстиции Российской Федерации 16.07.2012 (http://www.minjust.ru/ node $/ 2285$ ?theme $=$ minjust)

4. Сводная таблица Центральной избирательной комиссии Российской Федерации о результатах выборов депутатов Государственной Думы Фе-

\footnotetext{
7 Протокол избирательной комиссии Амурской области от 18 октября 2012 года о результатах выборов губернатора Амурской области
} 
дерального Собрания Российской Федерации второго созыва

5. Исследование ФОМ(Фонд Общественное Мнение) Нужны ли новые партии? (http://fom.ru/partii/10296)

6. Постановление № 26/1-5 от 16 октября 2012 года ЦИК России в Саратовской области

7. Протокол избирательной комиссии Амурской области от 18 октября 2012 года о результатах выборов губернатора Амурской области

8. Политическая наука: Соврем. состояние и перспективы развития : Пробл. темат. сб. / РАН. ИНИОН. Вып. 2, М. : ИНИОН РАН, 2005

9. 3.М. Зотова. Политические партии и избирательный процесс.- М. : РЦОИТ, 2002
10. Ю. М. Аксенов, О. Н. Попова Праймериз: исторический опыт, реалии и перспективы. - M: Восход-А, 2012

\section{References (transliteration):}

1. Anciferova I. V. Izbiratel'nyy process: sociologicheskiy analiz. M. - 2009

2. Z.M. Zotova. Politicheskie partii i izbiratel'nyy process.- M. : RCOIT, 2002

3. Yu. M. Aksenov, O. N. Popova Praymeriz: istoricheskiy opyt, realii i perspektivy. - M: Voshod-A, 2012 